Jurnal Penelitian Pendidikan Geografi Volume 4 No.1 Januari 2019

\title{
PERSEPSI MASYARAKAT BAJO TENTANG PENTINGNYA PENDIDIKAN FORMAL DI KELURAHAN WATOLO KECAMATAN MAWASANGKA KABUPATEN BUTON TENGAH
}

\author{
Eka Fitriani ${ }^{1}$
}

\author{
${ }^{1}$ Alumni Pendidikan Geografi Universitas Halu Oleo
}

\begin{abstract}
Abstrak : Tujuan penelitian adalah untuk mengetahui bagaimana Persepsi Masyarakat Bajo Tentang Pentingnya Pendidikan Formal di Kelurahan Watolo Kecamatan Mawasangka Kabupaten Buton Tengah. Jenis penelitian ini kualitatif dengan metode yang digunakan deskriptif. Penelitian lapangan menggunakan teknik pengumpulan data berupa observasi, wawancara, dan dokumentasi. Penentuan informan dalam penelitian ini menggunakan rumus Taro Yamane sehingga dari populasi 156 KK diperoleh informan sebanyak 35 KK. Dari hasil analisis data diperoleh kesimpulan bahwa: 1) Pengetahuan tentang pentingnya pendidikan formal pada masyarakat bajo di Lingkungan Jalan Layang dari 35 responden didapati hasil analisis rata rata skor sebesar 24 atau dengan persentase 69,52\%. 2) Pemahaman tentang pendidikan formal pada masyarakat bajo di Lingkungan Jalan Layang dari 35 responden didapati hasil analisis rata-rata skor sebesar 23 atau dengan persentase 64,29\%. (3) Kebutuhan akan pendidikan formal pada masyarakat bajo di Lingkungan Jalan Layang dari 35 responden didapati hasil analisis rata-rata skor sebesar 22 atau dengan persentase $62,86 \%$. (4) Pandangan terhadap pendidikan pada masyarakat bajo di Lingkungan Jalan Layang dari 35 responden didapati hasil analisis rata-rata skor sebesar 24 atau dengan persentase $69,21 \%$. Maka secara keseluruhan dapat disimpulkan Bahwa ternyata orangtua yang memiliki tingkat pendidikan yang rendah tidak mempengaruhi persepsi mereka dalam memotivasi atau memberikan dorongan kepada anak-anaknya untuk bersekolah dengan alasan ingin mengubah hidup dengan menyekolahkan anaknya agar nasib anaknya tidak sama dengannya.
\end{abstract}

Kata Kunci : Persepsi, Masyarakat Bajo, Pendidikan Formal 
Jurnal Penelitian Pendidikan Geografi Volume 4 No.1 Januari 2019

\title{
BAJO COMMUNITY PERCEPTION OF THE IMPORTANCE OF FORMAL EDUCATION IN WATOLO VILAGE MAWASANGKA DISTRICT CENTRAL BUTON TENGAH
}

\author{
Eka Fitriani ${ }^{1}$
}

${ }^{1}$ Alumni Of Halu Oleo University Geography Education

\begin{abstract}
The purpose of the study was to find out how the perception of the Bajo community about the importance of formal education in Watolo village, Mawasangka district, Central Buton regency. This type of research is qualitative with descriptive methods. Field research uses data collection techniques in the form of observation, interviews, and documentation. Determination of informants in this study using the Taro Yamane formula so that from the population of 156 families, the informants obtained 35 families. From the results of the data analysis, it can be concluded that: 1) Knowledge of the importance of formal education in Bajo people in the Street Flyover environment of 35 respondents was found to be an average score of 24 or $69.52 \%$. 2) Understanding of formal education in Bajo people in the flyover environment of 35 respondents found the results of the average score analysis of 23 or with a percentage of $64.29 \%$. (3) The need for formal education in Bajo people in the Flyover Environment of 35 respondents found the results of the average score analysis of 22 or with a percentage of $62.86 \%$. (4) The views on education in Bajo people in the Flyover Environment of 35 respondents found the results of the average score analysis of 24 or with a percentage of $69.21 \%$. So as a whole it can be concluded that it turns out that parents who have a low level of education do not influence their perception in motivating or encouraging their children to go to school with the reason of wanting to change their lives by sending their children to school so that their children's fate is not the same as him.
\end{abstract}

\section{Keywords : Perception, Bajo Community, Formal Education}

\section{PENDAHULUAN}

Indonesia merupakan negara kepulauan terbesar di dunia yang terdiri dari 17.508 pulau dengan garis pantai sepanjang $81.000 \mathrm{~km}$ dan luas laut sekitar 3,1 juta $\mathrm{km}^{2}$ $(0,3$ juta perairan teritorial; dan 2,8 juta $\mathrm{km}^{2}$ perairan nusantara) atau $62 \%$ dari teritorialnya. Wilayah pesisir dan lautan Indonesia terkenal dengan kekayaan dan keanekaragaman sumber daya alamnya, baik sumber daya yang dapat pulih (seperti perikanan, hutan mangrove dan terumbu karang) maupun sumber daya yang tidak dapat pulih (seperti minyak bumi dan gas serta mineral atau bahan tambang lainnya).

Kemajuan suatu bangsa ditentukan oleh kualitas sumber daya, baik sumber daya alam maupun sumber daya manusia. Kemajuan akan cepat dicapai bilamana didukung oleh sumber daya alam yang memadai dan sumber daya manusia yang berkualitas. Pemahaman tentang sumberdaya manusia mencakup dua hal utama, yaitu manusia sebagai insan dan manusia sebagai sumberdaya pembangunan. Kualitas manusia baik sebagai insan, maupun sebagai sumberdaya pembangunan, tidaklah muncul dengan sendirinya. Peningkatan kualitas sumberdaya manusia adalah hasil dari proses pembangunan untuk manusia dan bukan manusia untuk pembangunan (Rusli dkk, 1996).

Keberhasilan suatu pembangunan sangat ditentukan oleh keberhasilan di dalam membangun sumber daya manusia yang erat hubungannnya dengan pembangunan pendidikan secara menyeluruh, terarah dan terpadu, sehingga kualitas sumber daya manusia itu sendiri

Eka Fitriani 
dapat diselaraskan dengan segala sesuatu yang dibutuhkan oleh sektor pembangunan (Departemen Pendidikan dan Kebudayaan, 1995). Hal itu dapat menunjukan bahwa untuk membangun dan meningkatkan sumber daya manusia dapat dicapai melalui peningkatan pendidikan baik pendidikan formal, nonformal maupun informal.

$$
\text { Berdasarkan Undang-Undang }
$$

Sistem Pendidikan Nasional (UndangUndang SISDIKNAS) no. 20 tahun 2003 dinyatakan bahwa fungsi pendidikan nasional bertujuan untuk mengembangkan kemampuan untuk membentuk watak, serta peradaban bangsa yang bermartabat dalam rangka mencerdaskan kehidupan bangsa. (Wisma Willis, 2008).

Sekarang ini, dunia pendidikan belum menjangkau kesemua lapisan masyarakat. Berdasarkan observasi awal yang penulis lakukan masih sangat banyak anak yang belum mengecap atau merasakan pendidikan formal, padahal usia/umur mereka sudah layak untuk menduduki bangku sekolah dan problem semacam inilah yang terjadi di masyarakat suku Bajo di Kelurahan Watolo Kecamatan Mawasangka Kabupaten Buton Tengah. Melihat kasuistik seperti ini sangat perlu bagi penulis untuk mengeluarkan pemikiran yang lebih mendasar mengenai sebab sampai ada problematika publik tersebut. Sementara tingkat kepedulian pemerintah terhadap pendidikan di tempat ini sudah memadai, namun mengapa sampai hari ini peluang dari pemerintah itu tidak mereka gunakan sebaik mungkin. Memang sudah banyak perhatian pemerintah terhadap dunia pendidikan dan ternyata hal ini tidak bisa membuka mata masyarakat suku Bajo di Kelurahan Watolo Kecamatan Mawasangka Kabupaten Buton Tengah untuk berpartisipasi di dalamnya, mengingat apa yang telah dilakukan pemerintah tersebut semata-mata untuk mensejahterakan kehidupan bangsanya agar menjadi manusia-manusia yang berguna bagi negara dan sekaligus menciptakan SDM (sumber daya manusia) yang mampu bersaing dimasa mendatang baik secara intelektual maupun emosional.

Salah satu fenomena yang terlihat pada masyarakat Bajo Lingkungan Jalan Layang Kelurahan Watolo adalah tingkat kehidupan sosial masih berada dalam kondisi yang tergolong menengah kebawah. Hal ini ditandai dengan kondisi rumah hunian mereka masih menggunakan rumah panggung serta rendahnya tingkat pendidikan mereka. Rata-rata tingkat pendidikan masyarakat suku Bajo berhenti sampai batas SD dan hanya sedikit yang mengenyam pendidikan sampai tingkat SMP. Keadaan seperti ini bisa saja dipengaruhi oleh berbagai faktor, diantaranya yaitu faktor regulasi, kesadaran, atau karena kurangnya sarana dan prasarana.

Masyarakat Bajo Lingkungan Jalan Layang, Kelurahan Watolo, Kecamatan Mawasangka, menurut data yang di ambil dari Kantor Kelurahan Watolo Tahun 2017, dengan jumlah penduduk sebesar 727 jiwa, memiliki masalah yang cukup serius dibidang pendidikan. Hal ini tergambar dari tingkat pendidikan masyarakat Bajo Lingkungan Jalan Layang, Kelurahan Watolo yang tidak/belum sekolah 16,23\%, tamat sekolah dasar (SD) $45,81 \%$, SD/MI $17,75 \%$, SMP/MTS 13,06\%, SMA/SMK $6,74 \%$, dan Tingkat Perguruan Tinggi (S1) 0,41\%.(Kantor Keluraha Watolo)

Menurut Kamus Besar Bahasa Indonesia persepsi diartikan sebagai tanggapan (penerima langsung) dari sesuatu atau proses seseorang mengetahui beberapa hal melalui panca indranya. Persepsi merupakan tanggapan atau pengertian yang terbentuk dari suatu proses yang diperoleh melalui panca indra. Persepsi merupakan salah satu bagian dari kognisi, yaitu suatu proses pembentukan kesan tentang karakteristik dari sesuatu atau orang lain (Faturochman dalam Ariana 2011: 17).

Rahmad dalam Zainal (2010:7) mengemukakan bahwa persepsi itu adalah cara seseorang mengalami obyek-obyek dan gejala-gejala menurut suatu proses selektif. 
Selanjutnya Davidoff dalam Hazaruddin (2010:7) bahwa persepsi didefinisikan sebagai proses yang mengorganisir datadata indera kita untuk dikembangkan sedemikian rupa sehingga kita dapat menyadari sekeliling kita, termasuk sadar akan dirinya sendiri.

Menurut Gibson dalam Sarfan (2010: 8) persepsi adalah suatu proses yang terjadi dalam diri seseorang untuk memberikan arti kepada lingkungan, mengetahui dan menafsirkan serta menamakan berbagai macam stimulus ke dalam pengalaman psikologis serta tiaptiap orang memberi arti kepada stimulus, maka individu yang berbeda akan melihat situasi sering mempunyai arti yang lebih menyinggung untuk memahami perilaku dari situasi itu sendiri.

Dari uraian di atas dapat disimpulkan bahwasanya persepsi Berdasarkan beberapa pendapat di atas dapat ditarik kesimpulan bahwa persepai adalah seluruh proses akal manusia mengenai suatu cara pandang dan pemahaman seseorang mengenai suatu objek yang ada di sekitar lingkungannya melalui pengamatan, pengetahuan dan pengalamannya.

Menurut koentjaraningrat dalam sartika (2016 : 21), istilah masyarakat berasal dari kata arab syaraka yang berarti "ikut serta, partisipasi". Masyarakat adalah sekumpulan manusia yang saling "bergaul", atau dengan istilah ilmiah adalh "saling berinteraksi". Definisi lain, masyarakat adalah kesatuan hidup manusia yang berinterakasi menuru suatu sistem adat istiadat tertentu yang bersifat kontinyu,dan yang terkait oleh sesuatu rasa identitas bersama. Kontinuitas masyarakat yang memiliki keempat cirri yaitu: (1) Interaksi antar warga-warganya; (2) Adat istiadat; (3) Kontinuitas waktu; (4) Rasa identitas kuat yang mengikat semua warga (Koentjaraningrat, 2009: 115-118).

Pengertian Masyarakat yang diungkapkan oleh Abdulsyani (2007:30): "Kata masyarakat berasal dari musyarak (arab), yang artinya bersama-sama, kemudian berubah menjadi masyarakat, yang artinya berkumpul bersama, hidup bersama saling berhubungan dan saling mempengaruhi, selanjutnya mendapatkan kesepakatan menjadi masyarakat (Indonesia)".

Dari berbagai pengertian di atas dapat kita simpulkan bahwa persepsi masyarakat timbul karena adanya persepsi dari masing-masing individu di mana persepsi dari masing-masing individu tersebut terhadap suatu obyek dikumpulkan menjadi satu sehingga timbullah suatu persepsi masyarakat. Persepsi masyarakat merupakan proses mengamati obyek melalui indera kemudian diorganisasikan dan diinterprestasikan melalui bentukbentuk rangsangan suatu obyek atau peristiwa berdasarkan latar belakang masing-masing individu sehingga akan muncul tanggapan atau reaksi yang diwujudkan dalam bentuk kemampuan membeda-bedakan, mengelompokan, menyimpulkan informasi dan menafsirkan pesan serta terwujudnya komunikasi antara manusia dengan obyek.

Secara tertimologi Bajo adalah nama sekelompok masyarakat yang bermukim dilaut, dimana mereka bekerja sebagai nelayan secara turun temurun. Sekelompok masyarakat tersebut di Philipina Selatan disebut Bajau, di Malaysia disebut Saran dan di Indonesia popular dengan sebutan "Bajo" (Bahtiar, 2011: 73).

Menurut Soeparto (1989: 151) Masyarakat Bajo adalah orang-orang yang aktif melaksanakan kegiatan menangkap ikan baik secara langsung seperti menebar dan menarik jaring sedangkan secara tidak langsung seperti juru mudi perahu layar, nahkoda, ahli mesin, ahli listrik, dan juru masak. Situasi dan kondisi laut merupakan salah satu sumber tujuan masyarakat Bajo sebagai masyarakat nelayan dalam memenuhi kebutuhan hidupnya serta meningkatkan kesejahteraan hidupnya.

Masyarakat Suku Bajo dikenal sebagai masyarakat yang hidup (bermukim) 
di atas perairan. Adanya interaksi yang intensif antara masyarakat Suku Bajo dengan masyarakat yang hidup didarat menyebabkan terjadinya adopsi pola budaya oleh masyarakat Suku Bajo, termasuk pola pemukiman menetap dipinggir pantai hingga bermukim dimuara sungai. Tempat tinggal atau rumah Suku Bajo terletak di tepi laut, dan ada beberapa yang ada diatas permukaan air laut. Hal ini tidak lepas dari tradisi Suku Bajo yang identik dengan kehidupan laut dan mempunyai mata pencaharian utama sebagai nelayan.

Menurut Undang-Undang Sistem Pendidikan Nasional No.20 Tahun 2003 pendidikan adalah usaha sadar dan terencana untuk mewujudkan suasana belajar dan proses pembelajaran agar peserta didik secara aktif mengembangkan potensi dirinya untuk memiliki kekuatan spiritual, keagamaan, pengendalian diri, kepribadian, kecerdasan, akhlak mulia, serta keterampilan yang diperlukan didalam masayarakat.

Menurut Ahmad D. Marimba dalam (Manizar, 2009:8), pendidikan adalah bimbingan atau pimpinan secara sadar oleh si pendidik terhadap perkembangan jasmani dan rohani si terdidik menuju terbentuknya kepribadian yang utama.

Menurut Undang-Undang RI No. 20 Tahun 2003 pasal 1, pada dasarnya jenjang pendidikan (tingkat pendidikan) adalah tahapan pendidikan yang ditetapkan berdasarkan tingkat perkembangan peserta didik, tujuan yang ingin dicapai dan kemampuan yang dikembangkan. Jenjang Pendidikan seseorang akan mempengaruhi pandangan terhadap suatu yang datang dari luar. Orang yang mempunyai pandangan luas akan memberikan pandangan yang rasional daripada orang yang berpendidikan lebih rendah atau tidak berpendidikan sama sekali. Jadi jenjang pendidikan akan mempengaruhi sikap dan cara pandang seseorang. Dalam Pasal 17 Undang-Undang Sisdiknas No. 20 Tahun 2003 tentang Pendidikan Dasar, Pasal 18 UndangUndang Sisdiknas No 20 Tahun 2003 tentang Pendidikan Menengah, Pasal 19 Undang-Undang Sisdiknas No. 20 Tahun 2003 Tentang Pendidikan Tinggi, penjabarannya sebagai berikut:

1. Pendidikan Dasar

Pendidikan dasar adalah jenjang pendidikan yang melandasi jenjang pendidikan menengah. Bentuk satuan pendidikan dasar yang menyelenggarakan program 6 tahunan terdiri atas Sekolah Dasar (SD) dan Madrasah Ibtibaniyah (MI), sedangkan bentuk satuan program 3 tahun sesudah 6 tahun adalah Sekolah Menengah Pertama (SMP) dan Madrasah Tsanawiyah (MTs) atau bentuk lain yang sederajat (Pasal 7 Undang-Undang Sisdiknas No. 20 Tahun 2003).

2. Pendidikan Menengah

Pendidikan menengah adalah lanjutan pendidikan dasar yang terdiri atas pendidikan menengah umum dan menengah kejuruan. Bentuk satuan pendidikan menengah terdiri atas sekolah Menengah Atas (SMA), Madrasah Aliyah (MA), Sekolah Menengah Kejuruan (SMK), dan bentuk lain yang sederajat. Pendidikan menengah umum adalah pendidikan pada jenjang menengah yang mengutamakan perluasan pengetahuan dan peningkatan keterampilan masyarakat. Pendidikan Kejuruan adalah pendidikan pada jenjang menengah yang mengutamakan pengembaagan kemampuan masyarakat untuk melaksanakan jenis pekerjaan tertentu (Pasal 18 Undang-Undang Sisdiknas No. 20 Tahun 2003).

3. Pendidikan Tinggi

Pendidikan tinggi adalah jenjang pendidikan setelah pendidikan menengah yang mencakup program pendidikan Diploma, Sarjana, Magister Spesialis, Doktor, yang diselenggarakan pendidikan tinggi disebut Perguruan Tinggi yang dapat berbentuk akademik, politeknik, sekolah tinggi, institute, atau universitas (Pasal 19 dan 20 Undang-Undang Sisdiknas No. 20 Tahun 2003). 


\section{METODE PENELITIAN}

Jenis Penelitian

Penelitian ini adalah jenis penelitian deskriptif kualitatif, yaitu mendeskripsikan persepsi masyarakat bajo tentang pentingnya pendidikan formal di Kelurahan Watolo Kecamatan Mawasangka Kabupaten Buton Tengah.

Tempat dan Waktu Penelitian

Penelitian ini bertempat di Lingkungan Jalan Layang, Kelurahan Watolo, Kecamatan Mawasangka, Kabupaten Buton Tengah. Yang dimulai pada tanggal 09 sampai 15 April 2017.

Sampel Penelitian

Populasi dalam penelitian ini adalah seluruh kepala keluarga (KK) masyarakat bajo Lingkungan Jalan Layang Kelurahan Watolo, yang terdiri dari 156 kepala keluarga. Penentuan sampel dalam penelitian ini menggunakan rumus Taro Yamane dalam Riduwan (2004) yaitu:

$$
\mathrm{n}=\frac{\mathrm{N}}{\mathrm{N} \cdot \mathrm{d}^{2}+1}
$$

Keterangan :

$\mathrm{n}=$ Jumlah Informan

$\mathrm{N}=$ Jumlah Subyek

$\mathrm{d}^{2}=$ Presisi yang ditetapkan

Jumlah seluruh kepala keluarga (KK) masyarakat bajo $(\mathrm{N})=156 \mathrm{KK}$. Dengan presisi $\left(\mathrm{d}^{2}\right)$ adalah $15 \%$.

Dengan perhitungan :

$\mathrm{n}=\frac{\mathrm{N}}{\mathrm{N} \cdot \mathrm{d}^{2}+1}=\frac{156}{156 \cdot 0.15^{2}+1}=\frac{156}{3,51+1}=35$

Berdasarkan perhitungan tersebut, sehingga diperoleh jumlah informan penelitian ada 35 kepala keluarga (KK).

Variabel Penelitian

Adapun variabel penelitian ini adalah persepsi masyarakat Bajo tentang pentingnya pendidikan formal di Kelurahan Watolo Kecamatan Mawasangka Kabupaten Buton Tengah.

Instrument Penelitian

Instrumen dalam penelitian ini berupa:
a. Pedoman Interview
b. Pedoman Dokumentasi
c. Pedoman Wawancara

Instrumen penelitian digunakan sebagai acuan dalam pengumpulan data yang dilakukan dengan membagikan daftar pertanyaan berupa wawancara tertutup kepada responden dengan alternatif jawaban Ya/Tidak. Tiap item soal diberi skor 1 (satu) jika sesuai dan skor 0 (nol) jika tidak sesuai. Adapun instrumen dalam penelitian ini dapat dilihat pada tabel berikut:

Tabel 2.1 Kisi-kisi Wawancara

\begin{tabular}{|c|c|c|c|}
\hline Variabel Penelitian & Indikator & $\begin{array}{c}\text { Nomor } \\
\text { Pernyataan }\end{array}$ & $\begin{array}{l}\text { Jumlah } \\
\text { Item }\end{array}$ \\
\hline $\begin{array}{l}\text { Persepsi } \\
\text { Masyarakat Bajo } \\
\text { Tentang Pentingnya }\end{array}$ & $\begin{array}{lr}\text { Pengetahuan } & \text { tentang } \\
\text { pentingnya } & \text { pendidikan } \\
\text { formal } & \end{array}$ & $1,2,3$ & 3 \\
\hline $\begin{array}{l}\text { Pendidikan } \\
\text { di Formal } \\
\text { Kelurahan }\end{array}$ & $\begin{array}{ll}\text { Pemahaman } & \text { tentang } \\
\text { pendidikan formal } & \\
\end{array}$ & 4,5 & 2 \\
\hline $\begin{array}{l}\text { Watolo Kecamatan } \\
\text { Mawasangka }\end{array}$ & $\begin{array}{l}\text { Kebutuhan akan pendidikan } \\
\text { formal }\end{array}$ & $6,7,8,9,10,11$ & 6 \\
\hline $\begin{array}{l}\text { Kabupaten Buton } \\
\text { Tengah }\end{array}$ & $\begin{array}{ll}\text { Pandangan } & \text { terhadap } \\
\text { pendidikan } & \end{array}$ & $\begin{array}{c}12,13,14,15,16 \\
17,18,19,20\end{array}$ & 9 \\
\hline \multicolumn{3}{|c|}{ Jumlah } & 20 \\
\hline Sumber: Data diol & 2018) & & \\
\hline
\end{tabular}

Eka Fitriani 
Teknik Pengumpulan Data

Dalam penelitian ini teknik pengumpulan data dilakukan dengan cara sebagai berikut:

1. Observasi

Pengamatan terhadap objek penelitian untuk mengetahui persepsi masyarakat bajo terhadap pendi dikan formal di Kelurahan Watolo Kecamatan Mawasangka Kabupaten Buton Tengah.

2. Wawancara

Memberikan sejumlah pertanyaanpertanyaan secara langsung kepada seluruh informan yang berkaitan dengan persepsi masyarakat bajo terhadap pendidikan formal di Kelurahan Watolo Kecamatan Mawasangka Kabupaten Buton Tengah.

3. Dokumentasi

Pengambilan data-data yang berkenaan dengan masalah dalam penelitian ini yakni dokumen-dokumen yang relevan baik di Kelurahan Watolo maupun instansi-instansi lainnya.

Teknik Analisis

Sebelum di analisis data hasil penelitian terlebih dahulu diolah dengan tabulasi data dan editing untuk memudahkan analisis. Setelah semua proses skoring, tabulasi dan editing dilakukakan maka selanjutnya akan diinterprentasikan dan dijabarkan sesuai hasil yang didapati selama penelitian.

Untuk kesimpulan akhir terkait persepsi masyarakat Bajo tentang pentingnya pendidikan formal di Lingkungan Jalan Layang Kelurahan Watolo Kecamatan Mawasangka Kabupaten Buton Tengah, dilakukan dengan menyatakan persentase terbesar hingga terkecil dengan penggunaan rumus:

$\mathrm{P}=\frac{\mathrm{n}}{\mathrm{N}} \mathrm{X} 100 \%$

(Ali, 1985: 184)

Dimana:

$\mathrm{P}=$ Persentase nilai

$\mathrm{n}=$ Skor yang diperoleh setiap option

$\mathrm{N}=$ Jumlah sampel yang digunakan

\section{HASIL PENELITIAN}

\section{A. Persepsi Masyarakat Bajo Tentang Pentingnya Pendidikan Formal}

Berdasarkan hasil penelitian yang dilakukan yang mengkaji tentang persepsi masyarakat bajo tentang pentingnya pendidikan formal di Kelurahan Watolo Kecamatan Mawasangka Kabupaten Buton Tengah, dengan 20 pernyataan yang diberikan kepada 35 orang responden masyarakat bajo di Lingkungan Jalan Layang meliputi beberapa indikator diantaranya:

1. Pengetahuan Tentang Pentingnya Pendidikan Formal

Untuk mengetahui bagaimana pengetahuan masyarakat bajo di Lingkungan Jalan Layang tentang pentingnya pendidikan formal, maka diajukan tiga pertanyaan dapat dilihat pada tabel berikut:

Tabel 3.1 Pengetahuan Tentang Pentingnya Pendidikan Formal

\begin{tabular}{llll} 
No & Frekuensi & Persentase \\
\hline $\begin{array}{l}\text { Menurut Bapak/Ibu apakah pendidikan formal } \\
\text { sangat penting dalam pembentukan } \\
\text { kecerdasan anak }\end{array}$ & 27 & $77,14 \%$ \\
\hline $\begin{array}{l}\text { Apakah menurut Bapak/Ibu pengetahuan } \\
\text { orang tua dalam mendidik anak sangat } \\
\text { diperlukan }\end{array}$ & 25 & $71,47 \%$ \\
\hline $\begin{array}{l}\text { Apakah menurut Bapak/Ibu dengan } \\
\text { bersekolah itu merupakan sarana yang paling } \\
\text { baik untuk meningkatkan taraf hidup }\end{array}$ & 21 & $60,00 \%$ \\
\hline Sumber: Data diolah (2018) & & \\
\hline
\end{tabular}


Jurnal Penelitian Pendidikan Geografi Volume 4 No.1 Januari 2019

Tabel diatas dengan pertanyaan pertama bahwa dari keseluruhan sampel penelitian yang dilakukan dengan wawancara sebanyak 27 responden atau dengan persentase $77,14 \%$ bahwa merasa sekolah itu sangat penting dalam membentuk kecerdasan anak dan 8 responden atau dengan persentase $22,86 \%$ lainnya menyatakan bahwa mereka merasa sekolah itu tidak penting dalam membentuk kecerdasan anak.

Dari hasil penelitian yang dilakukan mendapatkan hasil analisis dari persent menunjukan bahwa $77,14 \%$ masyarakat bajo Lingkungan Jalan Layang sudah mengetahui bahwa sekolah itu penting dalam membentuk kacerdasan anak.

Pertanyaan kedua yaitu dari data hasil wawancara sebanyak 25 atau dengan persentase $71,43 \%$ masyarakat bajo di Lingkungan Jalan Layang merasa perlunya pengetahuan orangtua dalam mendidik anak dan 10 atau $28,57 \%$ merasa tidak perlunya pengetahuan orangtua dalam mendidik anak.

Dari penelitian yang dilakukan oleh peneliti mendapatkan hasil penelitian dari masyarakat bajo di Lingkungan Jalan Layang hasil dari persentase menunujukan
71,43\% masyarakat bajo di Lingkungan Jalan Layang bahwa perlunya orangtua memiliki pengetahuan dalam mendidik anak.

Pertanyaan ketiga dari tabel di atas maka, dari data hasil wawancara dengan jumlah 35 responden itu 21 responden atau dengan persentase $60,00 \%$ merasa dengan bersekolah itu bisa menjadi sarana yang paling baik untuk meningkatkan taraf hidup sedangkan, 14 responden atau dengan persentase $40,00 \%$ merasa sekolah itu tidak atau belum tentu bisa menjadi sarana yang paling baik untuk meningkatkan taraf hidup.

Dari penelitian yang dilakukan mendapatkan hasil penelitian dari masyarakat bajo di Lingkungan Jalan Layang hasil dari persentase menunujukan $60,00 \%$ masyarakat bajo di Lingkungan Jalan Layang menyatakan bahwa dengan bersekolah itu bisa menjadi sarana yang paling baik untuk meningkatkan taraf hidup.

2. Pemahaman tentang pendidikan formal Berikut ini untuk mengetahuai pemahaman masyarakat bajo di Lingkungan Jalan Layang tentang pendidikan formal. Hal ini dapat dilihat dalam tabel berikut:

Tabel 3.2 Pemahaman Tentang Pendidikan Formal

\begin{tabular}{llcc}
\hline No & \multicolumn{1}{c}{ Pertanyaan } & Frekuensi & Persentase \\
\hline $\begin{array}{l}\text { Menurut Bapak/Ibu anak yang } \\
\text { menempuh pendidikan formal akan } \\
\text { berbeda dengan anak yang tidak } \\
\text { menempuh jalur pendidikan formal }\end{array}$ & 23 & $65,71 \%$ \\
\hline $\begin{array}{l}\text { Menurut Bapak/Ibu perlukah orang } \\
\text { tua memperoleh pemahaman yang } \\
\text { benar mengenai pentingnya } \\
\text { menyekolahkan anak 22 }\end{array}$ & $62,86 \%$ \\
\hline
\end{tabular}

Sumber : Data diolah (2018)

Dari tabel diatas dengan pertanyaan pertama bahwa dari keseluruhan sampel penelitian yang dilakukan dengan wawancara sebanyak 23 responden atau dengan persentase $65,71 \%$ menunjukan bahwa anak yang menempuh pendidikan formal akan berbeda dengan anak yang tidak menempuh jalur pendidikan formal (berbeda dari segi pengetahuan, sikap, pola pikir dan lain-lain), sedangkan 12 responden atau dengan persentase $34,29 \%$ menunjukan bahwa anak yang sekolah dan tidak sekolah itu sama-sama saja.

Dari penelitian yang dilakukan hasil penelitian dari masyarakat bajo di Lingkungan Jalan Layang hasil dari persentase menunujukan $65,71 \%$ masyarakat bajo di Lingkungan Jalan 
Layang menyatakan bahwa anak yang sekolah dan tidak sekolah itu tidak sama (berbeda dari segi pengetahuan, sikap, pola pikir dan lain-lain).

Data hasil wawancara dengan pertanyaan kedua. Berdasarkan hasil jawaban 22 responden atau dengan persentase $62,86 \%$ merasa perlunya orangtua memperoleh pemahaman yang benar mengenai pentingnya menyekolahkan anak, 13 responden atau dengan persentase $37,14 \%$ menjawab merasa tidak perlunya orangtua memperoleh pemahaman yang benar mengenai pentingnya menyekolahkan anak.

Dari penelitian yang dilakukan mendapatkan hasil penelitian dari masyarakat bajo di Lingkungan Jalan Layang hasil dari persentase menunujukan $62,86 \%$ masyarakat bajo di Lingkungan Jalan Layang menyatakan bahwa perlunya orangtua memperoleh pemahaman yang benar mengenai pentingnya menyekolahkan anak.

3. Kebutuhan akan pendidikan formal

Berikut untuk mengetahui kebutuhan akan pendidikan formal pada masyarakat bajo di Lingkungan Jalan Layang. Hal ini dapat dilihat pada tabel berikut:

Tabel 3.3 Kebutuhan akan pendidikan formal

\begin{tabular}{llcc}
\hline No & \multicolumn{1}{c}{ Pertanyaan } & Frekuensi & Persentase \\
\hline 1. $\begin{array}{l}\text { Apakah Bapak/Ibu merasa sekolah itu } \\
\text { sangat dibutuhkan }\end{array}$ & 23 & $65,71 \%$ \\
\hline & $\begin{array}{l}\text { Apakah menurut Bapak/Ibu } \\
\text { pendidikan penting bagi masyarakat } \\
\text { Lingkungan Jalan Layang }\end{array}$ & 25 & $71,43 \%$ \\
\hline $\begin{array}{l}\text { Apakah anak-anak Bapak/Ibu } \\
\text { mempunyai keinginan untuk lanjut } \\
\text { sekolah ke jenjang yang lebih tinggi }\end{array}$ & 19 & $54,29 \%$ \\
\hline $\begin{array}{l}\text { Apakah anak-anak Bapak/Ibu } \\
\text { mempunyai sikap bertanggung jawab } \\
\text { dari proses pendidikan formal }\end{array}$ & 20 & $57,14 \%$ \\
\hline 5. Apakah anak-anak Bapak/Ibu ada \\
yang bersekolah
\end{tabular}

Sumber : Data diolah (2018)

Dari hasil wawancara pada indikator kedua pertanyaan pertama pada tabel diata, dengan petanyaan "Merasa sekolah itu sangat dibutuhkan" dengan jumlah 35 responden, 23 responden atau dengan persentase $65,71 \%$ bahwa merasa sekolah itu sangat dibutuhkan, 12 responden atau dengan persentase $34,29 \%$ merasa sekolah itu tidak dibutuhkan.

Dari penelitian yang dilakukan mendapatkan hasil penelitian dari masyarakat bajo di Lingkungan Jalan Layang hasil dari persentase menunujukan $65,71 \%$ masyarakat sangat butuh akan pendidikan formal.

Dari tabel diatas pertanyaan kedua dengan jumlah 35 responden, 25 responden atau dengan persentase $71,43 \%$ merasa bahwa sekolah itu penting bagi masyarakat Lingkungan Jalan Layang dan 10 responden atau dengan persentase $28,57 \%$ lainnya merasa sekolah itu tidak penting.. 
Dari penelitian yang dilakukan mendapatkan hasil menunujukan 71,43\% masyarakat bajo di Lingkungan Jalan Layang menyatakan bahwa sekolah itu penting bagi masyarakat Lingkungan Jalan Layang.

Data hasil wawancara pada pertanyaan ketiga, berdasarkan hasil jawaban 19 responden atau dengan persentase 54,29\% merasa Anak -anak Lingkungan Jalan Layang punya keinginan untuk lanjut sekolah ke jejang yang lebih tinggi, 16 responden atau dengan persentase $45,71 \%$ menjawab merasa Anak -anak Lingkungan Jalan Layang tidak menginginkan untuk lanjut sekolah ke jejang yang lebih tinggi.

Dari penelitian yang dilakukan mendapatkan hasil menunujukan 54,29\% masyarakat bajo di Lingkungan Jalan Layang menyatakan bahwa Anak -anak Lingkungan Jalan Layang punya keinginan untuk lanjut sekolah ke jejang yang lebih tinggi.

Dari tabel diatas pada pertanyaan keempat. Maka 20 responden atau dengan persentase $57,14 \%$ merasa anak-anak mereka mempunyai sikap bertanggung jawab yang tercipta dari proses pendidikan formal dan 15 responden lainnya atau dengan persentase $42,86 \%$ menunjukan bahwa anak-anak mereka tidak punya tanggung jawab dari proses pendidikan formal.

Dari penelitian yang dilakukan mendapatkan hasil penelitian dari persentase menunujukan 57,14\% masyarakat bajo di Lingkungan Jalan Layang menyatakan bahwa anak-anak mereka mempunyai sikap bertanggung jawab yang tercipta dari proses pendidikan formal.

Data hasil wawancara pada pertanyaan kelima, berdasarkan hasil jawaban 24 responden atau dengan persentase $68,57 \%$ bahwa anak-anak mereka ada yang bersekolah, 11 responden atau dengan persentase $31,43 \%$ menjawab anak-anak mereka tidak ada yang bersekolah atau belum sekolah.

Dari penelitian yang dilakukan oleh mendapatkan hasil penelitian dari persentase menunujukan 68,57\% masyarakat bajo di Lingkungan Jalan Layang menyatakan bahwa anak-anak mereka ada yang bersekolah.

Data hasil wawancara pada pertanyaan keenam. Berdasarkan hasil jawaban 21 responden atau dengan persentase $60,00 \%$ menjawab bahwa anak anak mereka bersekolah dengan baik, 14 responden lainnya atau dengan persentase $40,00 \%$ menunjukan bahwa anak-anak mereka tidak bersekolah dengan baik.

Dari penelitian yang dilakukan mendapatkan hasil penelitian dari persentase menunujukan 60,00\% masyarakat bajo di Lingkungan Jalan Layang menyatakan bahwa anak -anak mereka bersekolah dengan baik.

\section{Pandangan terhadap pendidikan}

Untuk mengetahui pandangan masyarakat bajo di Lingkungan Jalan Layang terhadap pendidikan formal maka dapat diajukan pertanyaan sebagai berikut:

Tabel 3.4 Pandangan Terhadap Pendidikan

\begin{tabular}{llcc}
\hline No & \multicolumn{1}{c}{ Pertanyaan } & Frekuensi & Persentase \\
\hline 1. & $\begin{array}{l}\text { Apakah ada harapan Bapak/Ibu dalam } \\
\text { menyekolahkan anak }\end{array}$ & 19 & $54,29 \%$ \\
\hline $\begin{array}{l}\text { Menurut Bapak/Ibu apakah semakin } \\
\text { tinggi tingkat pendidikan seseorang } \\
\text { maka status sosialnya dalam } \\
\text { masyarakat akan semakin tinggi juga. }\end{array}$ & 29 & $82,86 \%$ \\
\hline
\end{tabular}




\begin{tabular}{|c|c|c|c|}
\hline 3. & $\begin{array}{l}\text { Menurut Bapak/Ibu apakah dengan } \\
\text { bersekolah akan memberikan manfaat } \\
\text { dalam meningkatkan serta memberikan } \\
\text { informasi dan pemahaman terhadap } \\
\text { ilmu pengetahuan }\end{array}$ & 22 & $62,86 \%$ \\
\hline 4. & $\begin{array}{l}\text { Apakah menurut Bapak/Ibu sekolah } \\
\text { sangat penting untuk kehidupan }\end{array}$ & 27 & $77,14 \%$ \\
\hline 5. & $\begin{array}{l}\text { Menurut Bapak/Ibu apakah dengan } \\
\text { bersekolah bisa membantu dalam } \\
\text { memperoleh pekerjaan }\end{array}$ & 31 & $88,57 \%$ \\
\hline 6. & $\begin{array}{l}\text { Menurut Bapak/Ibu dengan bersekolah } \\
\text { bisa membantu tingkat ekonomi } \\
\text { masyarakat Lingkungan Jalan Layang }\end{array}$ & 21 & $60,00 \%$ \\
\hline 7. & $\begin{array}{l}\text { Apakah Bapak/Ibu sering memberikan } \\
\text { motivasi/dorongan kepada anak anda } \\
\text { untuk bersekolah. }\end{array}$ & 19 & $54,29 \%$ \\
\hline 8. & $\begin{array}{l}\text { Menurut Bapak/Ibu apakah uang } \\
\text { sekolah/biaya salah satu kesulitan } \\
\text { dalam menyekolahkan anak }\end{array}$ & 20 & $57,14 \%$ \\
\hline 9. & $\begin{array}{l}\text { Apakah dengan mampu membaca dan } \\
\text { menulis sudah cukup untuk } \\
\text { memperoleh pekerjaan yang layak }\end{array}$ & 30 & $85,71 \%$ \\
\hline
\end{tabular}

Sumber: Data diolah (2018)

Dari tabel diatas indikator keempat

pertanyaan pertama menunujukan bahwa 19

ressponden atau dengan persentase $54,29 \%$

pernyataan bahwa mereka memiliki harapan

dalam menyekolahkan anaknya dan 16

responden lainnya atau dengan persentase

$45,71 \%$ menunjukan bahwa mereka tidak memiliki harapan dalam menyekolahkan anak. Dari penelitian yang dilakukan mendapatkan hasil penelitian dari persentase menunujukan 54,29\% masyarakat bajo di Lingkungan Jalan Layang menyatakan bahwa mereka memiliki harapan dalam menyekolahkan anaknya.

Berdasarkan tabel di atas, dari hasil wawancara pada pertanyaan kedua, maka 29 responden atau dengan persentase $82,86 \%$ berpandangan bahwa semakin tinggi sekolahq seseorang maka status sosialnya dalam masyarakat akan semakin tinggi juga, sedangkan 6 responden lainnya atau dengan persentase $17,14 \%$ berpandangan bahwa semakin tinggi sekolah seseorang maka status sosialnya dalam masyarakat akan sama dengan masyarakat yang tidak bersekolah.

Dari penelitian yang dilakukan mendapatkan hasil penelitian dari persentase menunujukan 82,86\% masyarakat bajo di Lingkungan Jalan Layang menyatakan bahwa semakin tinggi sekolah seseorang maka status sosialnya dalam masyarakat akan semakin tinggi juga.

Data hasil wawancara pada tabel diatas dengan pertanyaan ketiga, berdasarkan hasil jawaban 22 responden atau dengan persentase $62,86 \%$ menyatakan bahwa sekolah akan memberikan manfaat dalam meningkatkan serta memberikan informasi dan pemahaman terhadap ilmu pengetahuan, sedangkan 13 responden lainnya atau dengan persentase $37,14 \%$ menjawab bahwa sekolah tidak atau belum tentu akan memberikan manfaat dalam m.eningkatkan serta memberikan informasi dan pemahaman terhadap ilmu pengetahuan. Dari penelitian yang dilakukan mendapatkan hasil penelitian dari persentase menunujukan $62,86 \%$ masyarakat bajo di Lingkungan Jalan Layang menyatakan bahwa sekolah akan memberikan manfaat dalam meningkatkan 
serta memberikan informasi dan pemahaman terhadap ilmu pengetahuan.

Data hasil wawancara pada tabel diatas dengan pertanyaan keempat, berdasarkan hasil jawaban 27 responden atau dengan persentase $77,14 \%$ menyatakan bahwa sekolah sangat penting untuk kehidupan, sedangkan 8 responden lainnya atau dengan persentase $22,86 \%$ menjawab bahwa sekolah tidak penting untuk kehidupan. Dari penelitian yang dilakukan mendapatkan hasil penelitian dari persentase menunujukan 77,14\% masyarakat bajo di Lingkungan Jalan Layang menyatakan bahwa sekolah sangat penting untuk kehidupan.

Berdasarkan tabel di atas, dari hasil wawancara dengan pertanyaan kelima, maka 31 responden atau dengan persentase $88,57 \%$ berpandangan bahwa dengan bersekolah bisa membantu memperoleh pekerjaan, sedangkan 4 responden lainnya atau dengan persentase $11,43 \%$ berpandangan bahwa tidak atau belum tentu dengan bersekolah bisa membantu memperoleh pekerjaan.

Dari penelitian yang dilakukan mendapatkan hasil penelitian dari persentase menunujukan $88,57 \%$ berpandangan bahwa dengan bersekolah bisa membantu memperoleh pekerjaan. Dari tabel diatas, dengan pertanyaan keenam, menunujukan 21 responden atau dengan persentase $60,00 \%$, sedangkan 14 responden lainnya atau dengan persentase $40,00 \%$ menyatakan bahwa tidak atau belum tentu dengan bersekolah bisa membantu meningkatkan ekonomi masyarakat Lingkungan Jalan Layang.

Dari penelitian yang dilakukan mendapatkan hasil penelitian dari persentase menunujukan 60,00\% masyarakat bajo di Lingkungan Jalan Layang menyatakan bahwa dengan bersekolah bisa membantu meningkatkan ekonomi masyarakat Lingkungan Jalan Layang.

Dari tabel diatas, data hasil wawancara dengan pertanyaan ketujuh, berdasarkan hasil jawaban 19 responden atau dengan persentase $54,29 \%$ menyatakan bahwa pernah memberikan dorongan kepada anak mereka untuk bersekolah, sedangkan 16 responden lainnya atau dengan persentase $45,71 \%$ menjawab bahwa tidak pernah memberikan dorongan kepada anak mereka untuk bersekolah. Dari penelitian yang dilakukan mendapatkan hasil penelitian dari persentase menunujukan $54,29 \%$ masyarakat bajo di Lingkungan Jalan Layang menyatakan bahwa pernah memberikan dorongan kepada anak mereka untuk bersekolah. Berdasarkan tabel di atas, dari hasil wawancara dengan pertanyaan kedelapan. Berdasarkan hasil jawaban 20 responden atau dengan persentase $57,14 \%$ menyatakan bahwa biaya sekolah menjadi salah satu kesulitan dalam menyekolahkan anak, sedangkan 15 responden lainnya atau dengan persentase $42,86 \%$ menjawab bahwa biaya sekolah tidak menjadi salah satu kesulitan dalam menyekolahkan anak.

Dari penelitian yang dilakukan mendapatkan hasil penelitian dari persentase menunujukan 57,14\% masyarakat bajo di Lingkungan Jalan Layang menyatakan bahwa biaya sekolah menjadi salah satu kesulitan dalam menyekolahkan anak.

Dari tabel diatas dengan pertanyaan kesembilan, menunjukan 5 responden atau dengan persentase $14,29 \%$ terhadap pernyataan bahwa dangan mampu membaca dan menulis sudah cukup untuk memperoleh pekerjaan yang layak dan 30 responden lainnya atau dengan persentase $85,71 \%$ menyatakan bahwa dangan mampu membaca dan menulis belum atau tidak cukup untuk memperoleh pekerjaan yang layak.

Dari penelitian yang dilakukan mendapatkan hasil penelitian dari persentase menunujukan $85,71 \%$ masyarakat bajo di Lingkungan Jalan Layang menyatakan bahwa dangan mampu membaca dan menulis belum tentu atau tidak cukup untuk memperoleh pekerjaan yang layak. 


\section{B. Deskripsi Rata-Rata Skor Persepsi Masyarakat Bajo Tentang Pentingnya Pendidikan Formal}

Berdasarkan sajian data hasil wawancara yang dilakukan peneliti dengan 35 responden masyarakat bajo di
Lingkungan Jalan Layang diperoleh ratarata skor terhadap persepsi masyarakat bajo tentang pentingnya pendidikan formal di Kelurahan Watolo Kecamatan Mawasangka Kabupaten Buton Tengah, seperti dapat dilihat pada tabel di bawah ini:

Tabel 3.5 Rata-rata persentase persepsi masyarakat bajo tentang pentingnya pendidikan formal

\begin{tabular}{clcc}
\hline No & $\begin{array}{c}\text { Persepsi Masyarakat Bajo Tentang } \\
\text { Pendidikan Formal }\end{array}$ & $\begin{array}{c}\text { Frekuensi } \\
\text { rata-rata } \\
\text { skor tiap } \\
\text { indikator }\end{array}$ & $\begin{array}{c}\text { Persentase } \\
\text { rata-rata tiap } \\
\text { indikator }\end{array}$ \\
\hline 1. $\quad \begin{array}{l}\text { Pengetahuan tentang pentingnya } \\
\text { pendidikan formal }\end{array}$ & 24 & $69,52 \%$ \\
\hline 2. & $\begin{array}{l}\text { Pemahaman tentang pendidikan } \\
\text { formal }\end{array}$ & 23 & $64,29 \%$ \\
\hline 3. & Kebutuhan akan pendidikan formal & 22 & $62,86 \%$ \\
\hline 4. & Pandangan terhadap pendidikan & 24 & $69,21 \%$ \\
\hline
\end{tabular}

Sumber : Data diolah (2018)

Berdasarkan tabel diatas diperoleh nilai rata-rata skor dari tiap indikator, yakni indikator pertama memuat pengetahuan tentang pentingnya pendidikan formal dengan rata-rata skor sebesar 24 atau setara dengan 69,52\%, indikator kedua pemahaman tentang pendidikan formal dengan rata-rata skor sebesar 23 atau setara dengan $64,29 \%$, indikator ketiga dengan rata-rata skor sebesar 22 atau setara dengan $62,86 \%$, dan indikator keempat dengan ratarata skor sebesar 24 atau setara dengan $69,21 \%$, dari keseluruhan responden sebanyak 35 responden.

Maka berdasarkan data tersebut peneliti melihat bahwa umumnya dari 35 responden yang mengkaji tentang persepsi masyarakat bajo tentang pentingnya pendidikan formal di Lingkungan Jalan Layang yang meliputi: Pengetahuan tentang pentingnya pendidikan formal pada masyarakat bajo di Lingkungan Jalan Layang dengan hasil analisis rata-rata sebesar 24 atau dengan persentase $69,52 \%$ menunjukan bahwa masyarakat bajo menganggap pendidikan formal merupakan suatu hal yang penting. Dengan menyekolahkan anak adalah untuk bekal hidup anak di masa yang akan datang dan memperoleh kehidupan yang lebih baik dibanding orangtuanya.

Pemahaman tentang pendidikan formal pada masyarakat bajo di Lingkungan Jalan Layang dengan hasil analisis rata-rata sebesar 23 atau dengan persentase 64,29\% menunjukan masyarakat bajo sudah memahami tentang pendidikan formal. Kebutuhan akan pendidikan formal pada masyarakat bajo di Lingkungan Jalan Layang dengan hasil analisis rata-rata sebesar 22 atau dengan persentase $62,86 \%$ menunjukan bahwa anak-anak masyarakat bajo mempunyai sikap bertanggung jawab dari proses pendidikan formal.

Pandangan masyarakat bajo terhadap pendidikan pada masyarakat bajo di Lingkungan Jalan Layang dengan hasil analisis rata-rata sebesar 24 atau dengan persentase $69,21 \%$. Masyarakat bajo berpandangan bahwa dengan memberikan dorongan atau motivasi kepada anak mereka untuk bersekolah kejenjang yang lebih tinggi agar dapat memperoleh pekerjaan dan kehidupan yang lebih baik. 


\section{KESIMPULAN}

Berdasarkan hasil penelitian dan uraian dalam pembahasan terhadap persepsi masyarakat bajo tentang pentingnya pendidikan formal di Kelurahan Watolo Kecamatan Mawasangka Kabupaten Buton Tengah pada tahun 2017/2018 dapat disimpulkan diantaranya sebagai berikut:

Bahwa ternyata orang tua yang memiliki tingkat pendidikan yang rendah tidak mempengaruhi persepsi mereka dalam memotivasi atau memberikan dorongan kepada anak-anaknya untuk bersekolah. Masyarakat bajo beranggapan bahwa orang yang berpendidikan akan lebih baik jika dibandingkan dengan yang tidak berpendidikan, dilihat dari latar belakang pengalaman kehidupan masyarakat bajo yang kurang baik dan tidak memiliki pendidikan. Hal inilah yang membuat masyarakat bajo tersebut ingin mengubah hidup dengan menyekolahkan anaknya agar nasib anaknya tidak sama dengannya.

\section{DAFTAR PUSTAKA}

Abdul Latif. 2009 Pendidikan Berbasis Nilai Kemanusiaan, Bandung: Refika Aditama.

Departemen Pendidikan dan Kebudayaan. 1995. Fungsi Keluarga dalam Peningkatan Kualitas Sumber daya Manusia. Jakarta: Depdikbud.

Dahuri Rokhmin dkk. 2004. "Pengelolaan Sumber Daya Wilayah Pesisir Dan Lautan Secara Terpadu”. PT. Pradnya Paramita, Jakarta.

Hernila dan Surdin. 2016. Kehidupan Sosial Ekonomi Masyarakat Bajo Di Desa Waburense Kecamatan Mawasangka Kabupaten Buton Tengah. Jurnal Penelitian Pendidikan Geografi Volume 1
No. 1 Januari 2016. Halaman 120

Kadriani dan La Harudu. 2017. Persepsi Masyarakat Nelayan Tentang Pentingnya Pendidikan Formal Di Desa Jawi-Jawi Kecamatan Bungku Selatan Kabupaten Morowali. Jurnal Penelitian Pendidikan Geografi Volume 1 No. 1 April 2017. Hal. 1-16

Manizar, Elly, 2009. Psikologi Pendidikan, Palembang: Rafah Press.

Nasution, Mulia, 2003. Manajemen Personalia. Bandung: Djambatan

Ucok Heriady Ridwan dan Sri Rum Giyarsih. Kualitas Pemukiman Masyarakat Suku Bajo di Daerah yang Berkarakter Pinggiran Kota dan Daerah Berkarakter Pedesaan di Kabupaten Muna. Jurnal Pembangunan Wilayah dan Kota, Volume 8 No.2.Halaman 1-8

Undang-Undang Nomor 20 Tahun 2003 tentang Sistem Pendidikan Nasional. 